\section{Multidisciplinary \\ SCIENTIFIC JOURNAL OF MARITIME RESEARCH}

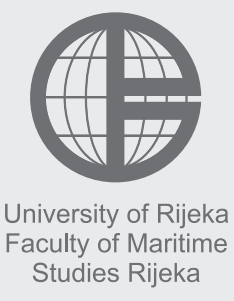

Multidisciplinarni znanstveni časopis POMORSTVO

\title{
Nautical Tourism in Croatia and in Portugal in the Late 2010's: Issues and Perspectives
}

\author{
Mirjana Kovačić ${ }^{1}$, Luís Silveira² \\ ${ }^{1}$ University of Rijeka, Faculty of Maritime Studies, Studentska 2, Rijeka, Croatia, e-mail: mirjana051@gmail.com \\ ${ }^{2}$ CEGOT / University of Coimbra, Colégio de São Jerónimo Largo da Porta Férrea, 3004-530, Coimbra, Portugal, e-mail: luis.silveira@uc.pt
}

\section{ABSTRACT}

Croatia is one of the well-known Mediterranean destinations for nautical tourism which full development potential is waiting to be used. Cultural attractions, indented coastline, numerous islands, climatic and other advantages are not enough. Croatia needs new infra- and supra-structures, which are reflected through investments in new marinas, anchorages and other facilities.

Portugal is an Atlantic country, but with a Mediterranean culture due to its proximity and (potentially) benefiting from its extensive shoreline, two archipelagos, and being located in a geographical position where thousands of yachts pass by each year.

The article aims to analyse the accommodation capacities of nautical tourism ports in Croatia and in Portugal. The authors have given an overview of the current situation with an emphasis on the differences and possibilities. The purpose of this article is to analyse the legal objective of nautical tourism and the growing need for accommodation capacities in ports of nautical tourism in both countries. The authors have carried out the research and have analysed data from different years and regions. Although more in Croatia, nautical tourism is a significant part of the national economy in both countries with a strong incentive on the local community. The special goal of this paper is to research into and analyse the economic and ecological impact of nautical tourism through ports of nautical tourism and with a special emphasis on marinas. The result obtained and the critical overview has been presented as one of the important contributions of this paper.
\end{abstract}

\section{ARTICLE INFO}

Preliminary communication Received 3 November 2018

Accepted 19 November 2018

\section{Key words:}

Nautical tourism

Marinas

Economic and ecological impact

Croatia

Portugal

\section{Introduction}

The Croatian coastline of the Adriatic Sea is $5,835 \mathrm{~km}$ long, of which $4,058 \mathrm{~km}$ belong to more than 1,000 islands [2]. It is well known that the Croatian coastline together with its well-indented coasts, clear sea and favourable climatic conditions is a paradise for yachtsmen.

As the nautical tourists interest grew, so did the required infrastructure develop, as well as marinas and ports for crafts accommodation, berths have been arranged, anchorages organised as well as numerous facilities for the boats and yachts supply and maintenance. Every year, the number of yachts and boats is increasing and so is the demand for berths. Many small ports, marinas and piers are desirable destinations for berthing during the summer season and every protected bay has become a berthing place. Due to the continual increase in yachts and boats that sail and, permanently or temporarily, stay at the east coast of the Adriatic Sea, the accommodation capacity of nautical ports is limited and consequently nautical tourists, especially those with longer yachts, deploy anchorages as their destination points.

Unlike Croatia, the coast of the Portuguese mainland is little cut and is at the mercy of the Atlantic. In this sense, marinas and recreational ports are the main points / structures for the accommodation of yachts and their yachtsmen. Nevertheless, nautical tourism is a segment of the tourist activity that increasingly captures the attention of Portuguese stakeholders. Due to its geostrategic position, every year thousands of yachts cross the Portuguese waters sailing from central and northern Europe to the Mediterranean (and vice versa), as well as yachts sailing from the Caribbean towards Europe (and the opposite) [22]. Due to the growth of nautical tourism over the last 
decades, the number of berthing places has not followed the number of boats and yachts, especially in Central and Northern Europe, which can be considered as an economic opportunity for Portugal if there are available berths in the marinas.

It is recognized that Portugal, with approximately 2,830 km of coast, $620 \mathrm{~km}^{2}$ of inland basins and two archipelagos has a good geographical position and navigability conditions. However, despite the recent trend of a substantial increase in the number of floating berths, the national supply is still relatively limited and therefore has a considerable potential for further growth. The goal of reaching a marina every 20 nautical miles (i.e. a four or less hour long voyage along the coast) is a legitimate ambition for the yachtsmen who frequent the Portuguese coast [4]. This situation is still far from being an ideal one.

Respecting the current reality and the necessity to develop nautical tourism as an important economic function in both countries, Croatia and Portugal, this paper aims to give an analysis of the nautical data, economic and ecological impact and possibilities of development.

\section{Theoretical Background}

Nautical tourism is one of the fastest growing segments of all maritime activities that begin to develop massively in the world alongside with all other forms of nautical tourism [3]. While other factors of the tourist offer (political, organizational, accommodation) can change and improve over time, the degree of the attractiveness of natural resources is a lasting and unchangeable value.

Nautical tourism is a specific form of tourism that includes vacation, leisure and recreation that, owing to its socio-economic impacts, represents an increasingly important growing tourist and economic potential. According to the new Law on Providing Tourism Services (Official Gazette of the Republic of Croatia (NN) No. 130/17), nautical tourism is defined as sailing and staying of tourists on board yachts, boats and cruisers for personal or business purposes, as well as berthing in nautical ports and nautical ports open for public transport, for pleasure, recreation/leisure and cruises.

According to the authors [9], [14], [22] and some other researchers, nautical tourism is related to the navigation seas, lakes and rivers. The motive for a voyage is recreation and pleasure on board yachts sailing by the sea and it is the key criterion to distinguish nautical tourism, among other forms of tourism. Nautical tourism has a complex structure and heterogeneous nature. Besides its own specific features, it also has elements of health, sport, excursion, culture and other similar forms of tourism.

Nautical tourism, specifically yacht tourism, corresponds to the navigation of small- and medium-sized sailing boats and/or motor yachts by individuals (potentially tourists) who sail using the marine environment and other points within the coastal areas (terrestrial environment) to rest, supply fuel and groceries, and usufruct, usually in the immediate vicinity of the structures and services that may or may not have a tourist vocation [22]. Yachting comprises a type of touring, entertainment, restful and sporty tourism carried out by medium-sized crafts [21].

This type of tourism, although it may also take place in inland waterways, is largely associated to the sea and the related activities. On inland waterways nautical areas or destinations, the nautical activities play a role of complementary tourist offer, being possible to be realized through some activities like sport fishing or sailing on lakes or nature reserves. However, the coastal areas offer additional opportunities because, in addition to the complementary tourist activities, the nautical structures (such as marinas) can play a role of a direct accommodation for tourist, given that nautical activities allow the movement of tourists over longer distances than in inland areas, even between countries and continents. Coastal facilities dedicated to carrying out such activities fulfil a dual function of complementary services and accommodation structures, as is the case with airports or railway stations [24].

At the European level, there is no global maritime categorization system. Instead, categorization usually occurs on a national level and with very different criteria from country to country. However, there are several international organizations that attest different characteristics of nautical tourism ports, more specifically of the marinas, but, as to their option, in the evaluation of the participation processes [12]. Some of these organizations and their distinctions, which attest the categorization of nautical ports at international level are: Foundation for Environmental Education (FEE) - Blue Flag, Société Générale de Surveillance (SGS) - Certification SGS and The Yacht Harbour Association TYHA Gold Anchor Scheme, etc.

The categorisation of nautical ports in the Republic of Croatia is carried out on the basis of the Law on Tourist Activity (Official Gazette of the Republic of Croatia (NN) No. 8/96, 19/96, 76/98, 76/99) and the Ordinance on the Classification and Categorisation of Nautical Ports (Official Gazette of the Republic of Croatia (NN), No. 142/99, 47/00, 121/00, 45/01 and 108/01). They are as follows: marinas, dry marinas, anchorage and berthing.

In the new Ordinance on the Classification and Categorisation of Nautical Ports (Official Gazette of the Republic of Croatia (NN), No. 72/08), which was issued in 2008 according to the Provision of Tourism Services Act (Official Gazette of the Republic of Croatia (NN,) No. $68 / 07$ ), there is a note that nautical ports holding a decision made according to the previous Ordinance shall not be the subject of harmonisation with the new one. According to the new Ordinance (Official Gazette of the Republic of Croatia (NN), No. 72/08), the port of nautical tourism is defined as a business functional entity in which a legal or natural person operates and provides tourist services in nautical tourism and other services in the function of tourist consumption (trade, catering, etc.). The marina is defined as a part of the water space and coastline specially constructed and arranged for providing link services, tourist accommodation in crafts and other services in accordance with this Ordinance. The type of marina 
is marked by anchors (two anchors, three anchors, four anchors, five anchors).

In Portugal, there are no regulations at the national level for the definition and differentiation of various support structures for sport and leisure purpose boating. The names used for a marina, nautical tourism port, berth and pier, are defined by the very entities that build and/or manage these structures. However, the Portuguese official journal (Diário da República) presents definitions for the marina, nautical tourism port and berths. The first structure, the marina, is defined as the set of infrastructures located in sheltered water plan, exclusively intended for tourism, sports and leisure, having ashore the necessary supports to the boats and their crews, and framed by a hotel and residential complex. The nautical tourism port is considered as a set of maritime, river and terrestrial infrastructures in a sheltered water plan, intended for the sport and leisure purpose boating and having the necessary supports for crews and boats. A nautical tourism berth is considered as a ramp infrastructure that allows boats to access the water level.

\section{Analyses of Croatian Nautical Tourism}

Croatia is today one of the very popular nautical destinations. This is the result of its position on the Mediterranean, along one of the most indented coastlines in the world, with a pleasant climate and favourable winds and safe for nautical tourists and their yachts. Some authors [25] have pointed out that nautical tourism in Croatia has developed thanks to its pristine coastline with numerous bays, coves and islands, its clean and pleasantly warm sea, and the great variety and contrasts in the landscape due to the suitable Mediterranean climate.

\subsection{Present Conditions}

Contrary to the world trends, the development of nautical tourism in Croatia was slower until the early 1980's. An intensified development of nautical tourism started with the foundation of the Adriatic Croatia International Club, for the activities of marinas (ACI d.d.), which initiated the construction of 16 marinas (Umag, Rovinj, Pula, Pomer, Rab, Supetarska Draga, Žut, Piškera, Vodice, Skradin, Jezera, Trogir, Split, Milna, Vrboska and Palmižana). By the end of the 1980's, marinas were built in Korčula and Opatija, and in the early 1990's in Dubrovnik, Šimuni and Cres too. The last marina built by the ACI organisation is the one in Slano, near Dubrovnik, which started working in 2017. Alongside the development of the ACI marinas, other marinas along the Croatian coast have also been built. The number of all ports of nautical tourism in Croatia in the period from 2006 to 2016 is shown in Table 1. According to the Croatian Bureau of Statistics [1], in 1993, there were only 37 marinas with 9,924 berths, while in 1999 there were 55 marinas with 12,43,7 berths. In 2003, Croatia had a total of 75 ports of nautical tourism, including marinas with 14,730 berths.

The total number of ports of nautical tourism on the territory of Croatia in the observed ten-year period was constantly increasing; indeed, it increased by $46 \%$, or by 44 nautical tourism ports, reaching the number of 58 marinas in 2016. However, the ports of nautical tourism along the Croatian coast are not evenly distributed. The area of mid-Adriatic has doubled the number of ports of nautical tourism, particularly the County of Zadar, which, with its 20 newly built ports, has taken the lead in the number of ports of nautical tourism along the entire

Table 1 Ports of Nautical Tourism in the Republic of Croatia from 2006 to 2017

\begin{tabular}{|c|c|c|c|c|c|c|c|}
\hline \multirow[b]{2}{*}{ YEAR } & \multicolumn{7}{|c|}{ COUNTY } \\
\hline & $\begin{array}{l}\text { DUBROVNIK- } \\
\text { NERETVA }\end{array}$ & $\begin{array}{c}\text { SPLIT- } \\
\text { DALMATIA }\end{array}$ & ŠIBENIK-KNIN & ZADAR & ISTRIA & $\begin{array}{c}\text { PRIMORJE- } \\
\text { GORSKI KOTAR }\end{array}$ & TOTAL \\
\hline 2006 & 6 & 11 & 11 & 24 & 14 & 29 & 95 \\
\hline 2007 & 5 & 11 & 11 & 23 & 14 & 30 & 94 \\
\hline 2008 & 5 & 11 & 11 & 24 & 14 & 32 & 97 \\
\hline 2010 & 5 & 13 & 11 & 24 & 15 & 30 & 98 \\
\hline 2011 & 6 & 13 & 13 & 21 & 15 & 30 & 98 \\
\hline 2012 & 6 & 16 & 13 & 19 & 15 & 29 & 98 \\
\hline 2013 & 6 & 17 & 14 & 23 & 14 & 32 & 106 \\
\hline 2017 & 8 & 27 & 21 & 46 & 12 & 26 & 140 \\
\hline
\end{tabular}

Source: Authors according to Nautical Tourism, Capacity and Turnover of Ports, various years, www.dzs.hr, https://www.dzs.hr/Hrv_Eng/publication/ 2017/04-03-04_01_2017.htm 
Table 2 Nautical Tourism Ports in Croatia in 2017 as per Counties

\begin{tabular}{|c|c|c|c|c|c|c|c|c|c|}
\hline \multirow[b]{2}{*}{ County of } & \multirow[b]{2}{*}{ Total } & \multirow[b]{2}{*}{$\begin{array}{l}\text { Anchora- } \\
\text { ge }\end{array}$} & \multirow[b]{2}{*}{$\begin{array}{l}\text { Moo- } \\
\text { ring }\end{array}$} & \multicolumn{5}{|c|}{ Marinas } & \multirow[b]{2}{*}{$\begin{array}{c}\text { Uncategori- } \\
\text { sed } \\
\text { nautical } \\
\text { tourism } \\
\text { ports }\end{array}$} \\
\hline & & & & $\begin{array}{c}\text { Boat } \\
\text { places } \\
\text { on land }\end{array}$ & $\begin{array}{c}\text { Marina, } \\
1^{\text {st }} \text { cate- } \\
\text { gory }\end{array}$ & $\begin{array}{c}\text { Marina, } \\
2^{\text {nd }} \text { cate- } \\
\text { gory }\end{array}$ & $\begin{array}{c}\text { Marina, } \\
3^{\text {rd }} \text { cate- } \\
\text { gory }\end{array}$ & $\begin{array}{c}\text { Marina, } \\
\text { categoria- } \\
\text { sed and } \\
\text { marked } \\
\text { by anchors }\end{array}$ & \\
\hline Republic of Croatia & 140 & 61 & 6 & 13 & 5 & 16 & 17 & 19 & 3 \\
\hline Šibenik-Knin & 21 & 7 & - & 1 & 2 & 3 & 5 & 3 & - \\
\hline Split-Dalmatia & 27 & 12 & 1 & 2 & - & 3 & 3 & 5 & 1 \\
\hline Istria & 12 & - & 1 & - & 2 & 2 & 2 & 5 & - \\
\hline Dubrovnik-Neretva & 8 & 1 & - & 1 & - & 2 & - & 2 & 2 \\
\hline
\end{tabular}

Source: Authors according to Nautical Tourism, Capacity and Turnover of Ports, www.dzs.hr, https://www.dzs.hr/Hrv_Eng/publication/2017/ 04-03-04_01_2017.htm

Croatian coast. On the other hand, the southern part of Croatia has the least number of ports of nautical tourism, while their number in the Counties of Primorje-Gorski Kotar and Istria varied over the ten-year period. Contrary to other counties, the County of Lika-Senj still records no development in the direction of nautical tourism. The inadequate number of berths is a problem in the whole of Croatia. Particularly worth noting is the lack of available berths for boats of 12 to 15 meters in length and the growing demand for berths for yachts of more than 20 meters in length, as well as the lack of additional services/offers. Despite significant investments in tourist services and facilities, nautical tourism is stagnant, especially in the County of Primorje-Gorski Kotar and Istria.

In 2017, the Croatian Bureau of Statistics [1] carried out a research of the capacity of nautical tourism ports. It covered 140 nautical tourism ports along the Croatian coast including 70 marinas (of which 13 land marinas) and 70 other nautical tourism ports (Table 2). The total water surface area was 3,711,951 $\mathrm{m}^{2}$ and there were 17,067 berths. The number of yachts on permanent berths remained at the same level as in 2016. On $31^{\text {st }}$ December 2017, there were 13 thousand yachts permanently berthed in nautical tourism ports, which was $0.1 \%$ more than on $31^{\text {st }}$ December 2016. There were $86.7 \%$ of the yachts that used berths, while $13.3 \%$ of them used boat places on land. As for the type of permanently berthed crafts that used water moorings, the majority were sailing boats $(51.0 \%)$, followed by motor yachts (45.6\%) and other crafts (3.4\%). As for the flag flying, the largest number of permanently berthed crafts came from Croatia (42.5\%), followed by those from Austria (16.5\%), Germany (16.0\%), Slovenia (5.0\%), Italy (4.7\%), and the United Kingdom (2.6\%). According to CBS, in 2017, there were 202 thousand crafts in transit in nautical tourism ports, which was $1.9 \%$ more than in 2016 , representing an increase in the number of crafts in transit as compared to the year 2016. As for the type of crafts in transit that used water moorings, the majority $(65.7 \%)$ were sailing boats, followed by motor yachts (29.7\%) and other crafts (4.6\%). In 2017, the largest number of crafts in transit came from Croatia (46.0\%), Italy (15.0\%), Germany (12.6\%), Austria $(7.3 \%)$ and Slovenia $(3.8 \%)$, which makes $84.7 \%$ of the total number of crafts in transit.

\subsection{Economic and Ecological impact}

According to some authors [6], nautical tourism has a very high multipliable effect, allowing it to become one of the most competitive products of Croatia in the world. Other authors [8] have pointed out that nautical tourism has strong incentive in tourism economy, more than $20 \%$, and a very strong incentive to the development of local comunities.

By the CBS, the total income realised in nautical tourism ports in 2016 was about 8\% lower than in 2015 . However, despite this evident decline, the ports of nautical tourism are taking a more significant place in the overall tourist balance of the County of Primorje-Gorski Kotar. A similar decline has been also noted in the County of Istria, while other coastal counties have recorded an increase.

The total income realised in nautical tourism ports in 2017 amounted to 855 million kunas (or 115,50 million euros) [1]. Out of that, 598 million kunas / 80,8 million euros have been realised by renting berths, representing, $70.0 \%$ of the total realised income. As compared to the year 2016, the total income increased by $11.2 \%$ and the income from renting berths by $10.9 \%$ what is $70.0 \%$ of the total realised income. The number of employed persons in nautical tourism ports, in 2017, amounted to 1665 . From this number, 448 were employed as seasonal workers.

Still, the growing demand for new berths has to be controlled and sustainable. It was emphasized [7] that the effects that marinas have on the environment involve immediate direct and indirect impacts of construction phases (loss of habitats, changes in sea quality and sedimentation), permanent impacts (loss of scenery and landscapes, permanent decline of sea quality, growing noise 
levels, and growing local pressure resulting, for example, from traffic). Since the Adriatic Sea is a deeply indented bay of the Mediterranean Sea, the necessity of reaching a compromise between the need for environmental protection of the sea and the need for an economic development of nautical tourism, is always very important. This means that the protection of the marine environment involves all measures and procedures in order to prevent pollution from yachts and boats. Preventive measures refer to all measures in compliance with regulations stipulating the safety of yachts and boats, including seaworthiness of yachts and boats as well. Corrective measures primarily have to include procedures for minimising the damage caused by pollution.

\section{Analyses of Nautical Tourism inPortugal}

Sport/leisure boating and yachting in Portugal is a relevant sector in the national economy and of particular socioeconomic importance in many places, either by the number of tourist, by the connection to the communities, or by both, as it is an increasing reality of mutual benefit, conferring identity to the destination and economic benefits to the population [17]. However, the offer still does not meet the international requirements for an available number of the berths for yachts passing by and wishing to visit the area. Within the context of supply, the country bordering on the Atlantic Ocean, with a low indented coastline and an unequal distribution of nautical ports, are factors that need to be taken into account based on a better and careful planning of the future economy associated with nautical tourism.

\subsection{Present Condition}

In 2018 (without changes since 2016) [22], Portugal has had 54 nautical ports (Table 3 ). The marinas correspond to the majority of structures $(n=29,53.7 \%)$ which means, at the outset, structures with a greater capacity in the number of berth and in a greater number of support services to the boats and yachts and their crews. This information should, however, be carefully analysed because of the Portuguese law subjectivity in relation to the definition of each nautical port and the freedom that managers have to choose the designation or nomenclature to the respective port under its management. For example, in the Azores some of the nautical ports that are named as marinas practically do not have support services as opposite to Lisbon, where some recreational berths have a large berthing capacity and have various support services for yachtsmen and boaters. Centro is the region with the greatest number of nautical ports (12) in Portugal, but this number is not a representative one as of its real berth capacity offer, since only four (4) nautical ports fulfil the condition of having a navigable access for larger yachts or are officially open to yachtsmen passing by. The majority are only oriented to resident yachtsmen. This situation extends to other regions so that, in that sense, the number of nautical tourism ports and the number of berths in Portugal, with the capacity of accommodating yachts and boats in transit, is even much lower.

The first berthing offer, through the existence of nautical tourism ports especially intended for yachts, started in the year 1970 with 286 berths (Table 4). The marina of Vilamoura (Algarve) is one of the oldest as it accommodated its first yacht in 1974. Today, it is the largest Portuguese marina, with 825 berths. In addition to and over the years, it has received the Five Anchors award by the Yacht Harbour Association and, in 2016, won, for the $6^{\text {th }}$ consecutive year, the prize for the Best Portuguese Marina, awarded by Publituris Portugal Trade Awards. In 2015 and in 2016, the marina was selected the Best International Marina, by TYHA. The 1990's and the 2000's were important for Portugal, having been a turning point for the attention to be given to the sea. The 1998 World Expo in Lisbon, through its preparation and seen as a good example to follow, was a remarkable one, giving rise to the policy of the coast approaching the sea. In the last years, the Azores regional government has invested into the construction of nautical tourism ports on these islands and some nautical tourism ports on the Portuguese mainland have invested in their berth capacity increase. Thus, in 2016, there were 12,739 berthing places in Portugal. The region of Algarve, through its marinas (main references in

Table 3 Ports of Nautical Tourism in Portugal as per Regions

\begin{tabular}{|c|c|c|c|c|}
\hline Country and regions & Total & Marinas & Nautical tourisml ports & Nautical tourist berths \\
\hline Portugal & 54 & 29 & 17 & 0 \\
\hline Norte & 6 & 6 & 0 & 0 \\
\hline Centro & 12 & 4 & 2 & 4 \\
\hline Lisbon & 10 & 4 & 1 & 0 \\
\hline Alentejo & 2 & 1 & 4 & 3 \\
\hline Algarve & 11 & 4 & 1 & 0 \\
\hline Madeira & 4 & 3 & 2 & 0 \\
\hline Azores & 9 & 7 & & \\
\hline
\end{tabular}

Source: adapted from Silveira (2016) 
Table 4 Increase in the Number of Berths in Portugal

\begin{tabular}{|l|c|c|c|c|c|c|}
\cline { 2 - 7 } \multicolumn{1}{c|}{} & \multicolumn{5}{c|}{ Portugal } \\
\hline Year & 1970 & 1980 & 1990 & 2000 & 2005 & 2016 \\
\hline Number of berths & 286 & 1271 & 1327 & 5292 & 9900 & 12739 \\
\hline
\end{tabular}

Source: adapted from Cabral (2007, cited by Sousa, Fernandes \& Carpinteiro, 2009) and Silveira (2016)

the national and international context), together with four nautical tourism ports and three nautical tourist berths represents $31.5 \%$ of all the berths located in the country [22].

\subsection{Economic and Ecological impact}

Between the years 2011 and 2015, the number of newly checked-in yachts was of 16,800 and 17,200 [19]. From these total amount and according to Table 5, three countries from Central Europe (France, the United Kingdom and Germany) accounted for the majority (51\%) of yachtsmen visiting the nautical tourism ports in Portugal. Crews from Portugal have a representity of $21 \%$. Although Spain is an important market and geographically close to Portugal, it includes only $6 \%$ of the newly checked-in crews.

Table 5 Nationality of the Newly checked-in Crafts' Crews Visiting Nautical Ports in Portugal between 2011 and 2015

\begin{tabular}{|l|c|}
\hline \multicolumn{1}{|c|}{ Country } & Percentage from 2011 to 2015 \\
\hline France & $21 \%$ \\
\hline Portugal & $21 \%$ \\
\hline United Kingdom & $16 \%$ \\
\hline Germany & $9 \%$ \\
\hline Netherlands & $6 \%$ \\
\hline Spain & $6 \%$ \\
\hline Other & $21 \%$ \\
\hline Total & $100 \%$ \\
\hline
\end{tabular}

Source: Adapted from PwC (2016)

Sport / leisure boating is an activity that, although identified by the Portuguese government and stakeholders as a strategic sector for the national development, remains a poorly studied segment, as well as the almost non-existence of information and statistics on the sector as a whole. This is due to different management models in nautical tourism ports. Although all nautical tourism ports are in the public domain, some have private management or are managed by nautical/yachting clubs, and some have a public manager (usually related to the administration of commercial seaports). There is a lack of a national entity that collects data and produces statistics and studies to obtain a better understanding of the reality of yachting and boating in the country. However, there are some entities in Portugal that bring together some nautical tour- ism ports under the same vision and/or macro strategy of action. Among them and on the Portuguese mainland, there is the Portuguese Association of Recreational Ports (APPR) and Docapesca Portos e Lotas S.A. In the autonomous archipelagos and regions of the Azores and Madeira, regional governments represent the management responsible for the majority of nautical tourism ports.

Regarding the impacts of yachting and boating in Portugal, Docapesca presented a report on the economic and tourist impact for the development of recreational boating in the 11 marinas and nautical touriml ports under its jurisdiction. These nautical tourism ports are located in three regions: one nautical port in the Norte region, three in the Centro region and seven in Algarve. Together they represent a total of 4477 berths [17]. Since Algarve is the main tourist region in Portugal for Sea, Sun and Sand tourism, coastal tourism with the Mediterranean natural and human influences (Mediterranean as a macro international region of great importance for nautical tourism), this report is relevant to get a closer notion of the real and the potential economic impact of nautical tourism in Portugal. It is an exploratory model, which should be understood as the first test for future developments and adjustments. It was based on: (1) seasonality: the model incorporates, in a differentiated way, the expenses and occupancies in high and low season (and average season when applicable); (b) insertion of a nautical model in the community: the model internationalizes the different behaviours and respective type of expenditure according to whether the demand is carried out by resident yachtsmen (in the municipality or in the infrastructure region) or non-resident ones (all other yachtsmen); c) maritime tourism vs. coastal tourism: the results take into account the relationship between the effects of direct spending on nautical tourism (represented here by the nautical pleasure proxy) and coastal tourism through the immediate multiplier effect of the costs of the nautas on the land based infrastructures shared with other tourists [17].

Based on the set of these 11 nautical ports, the tourists or yachtsmen stopping by, spend an expense between $140,275,770$ to $169,725,932$ euros (Table 6). That is, tendentiously $92.9 \%$ of the total expenditure of recreational boating and yachting in the area influenced by the jurisdiction of Docapesca. When analysing the expenses by activity - nautical tourism vs. coastal tourism (both directly related to yachtsmen and boating), it is noted that the direct expenses from nautical tourism can range from a minimum of $39,136,543$ euros to a maximum of $47,353,055$ euros. Direct expenses from coastal tourism can range 
from a minimum of $111,909,169$ euros to a maximum of $135,403,912$ euros. The expenses of nautical tourism are related to services such as cost of berthing, mechanic's workshop services, painting and fiber services, overhauling in a shiprepairard, ship and electronic communications services, carpenter's and upholsterer's charges, ship's equipment shop, fuel and gas supply, laundry, nautical clothing and footwear. These three have already shared with the coastal tourism. Coastal tourism expenses are related to services as public transport, supermarkets and grocery stores, catering and cafés, hotel accommodation, air transport [17].

If extrapolating the minimum and maximum values, calculated for the whole of 4477 berths of Docapesca, for the total of 12739 berths in Portugal, we will have a direct economic impact from nautical tourism as a whole varying from a minimum of $429,790,334$ euros to a maximum of $520,022,560$ euros.

Table 6 Total Direct Expenditures in Tourism as per Yachtsmen Origin

\begin{tabular}{|l|c|c|}
\hline \multirow{2}{*}{\multicolumn{1}{|c|}{ Yacthsmen origin }} & \multicolumn{2}{c|}{ Direct expenses in euros } \\
\cline { 2 - 3 } & Minimum & Maximum \\
\hline Non-resident yachtsmen & $140,275,770$ & $169,725,932$ \\
\hline Resident yactshmen & $10,769,942$ & $13,031,035$ \\
\hline Total & $151,045,712$ & $182,756,967$ \\
\hline
\end{tabular}

Source: adapted from Perna, F., Custódio, M, and Oliveira, V. (2015)

Due to the characteristics of the Atlantic Ocean and the poor indented coast of Portugal (less favourable to the navigation of small- and medium-size ships), as well as the existence of some sparsely populated areas or areas distant from larger urban centres (Alentejo and Centro regions), it makes hard to justify large investments (and the potential economic return) on the construction or adaptation of nautical tourism ports. Forty-one nautical tourism ports out of the 54 existing in the country are located in the mainland of Portugal (the remaining ones along the Atlantic coast and south coast with a Mediterranean influence). Their distribution is not uniform, some ports are concentrated at the mouth of rivers such as the Vouga and Tagus, which makes the distribution of ports along the coast even more sparse. Therefore, the Portuguese Atlantic coast is characterized by great distances related to nautical tourism ports and even with no nautical tourism ports to support yachts and boats and, consequently, without nautical tourism as well.

With regard to the relationship between development and sustainability, the model of development, being balanced among the three macro elements: the economic, social and environmental one, will become increasingly crucial. As part of the new tourist typology (greater purchasing power, higher education, greater environmental concern), the nautical population is becoming aware of its environmental behaviour and of the resulting practices in berthing. In the time when climatic changes indicate and motivate the change in the consumption behaviour in a generic way, tourism and the environment will increasingly become inseparable. In this sense, the marinas that more quickly adapt themselves (through their offer) to the present and future environmental practices of yacthsmen and boaters, will have a greater potential for their economic and institutional success. Due to the rapid erosion of the Portuguese Atlantic coast, coastal planning plans are already in operation. This set of measures for the protection, sensitiveness and action should also include Portuguese nautical tourism ports in order to more quickly adapt them to the climatic changes and, consequently, to be more competitive with other markets.

\section{Result and Discussion}

Considered integrally, the Croatian and Portuguese coastal area (sea, ocean and land) is, potentially. one of the most important natural resources to be further developed. This development has to be permanent or sustainable over a longer period of time, pointing out the importance of the rational managing of natural resources, among which open space is one of the most significant.

\subsection{Differences and Similarities}

It is known, and lot of authors agree that the composition, richness and attractiveness of its natural resources place Croatia ahead of many European tourist countries. When compared with the competitive countries such as Spain, France, Italy, Portugal, Greece and Turkey, Croatia is constantly rated better than its competitors with respect to personal safety, beauty and preservation of the nature and the environment, mild climate and purity of the sea and the coastal area, as well as to some social elements, like hospitality and the image it has as a country. According to the research carried out by Tomas Nautika Yachting in 2017 [5] Croatia's comparative advantages are its natural beauty, landscape imagery and ecological preservation, which represent all important, but at the same time not sufficient, features for the development and future of nautical tourism. The development of nautical tourism is conditioned not only by the attractiveness of natural beauty spots that Croatia is abound with, but also by adequate marinas, moorings, berths and other accompanying facilities. In addition to the physical advantages of the Croatian coast, it is important to consider how berthing capacities have to be dispersed along the Croatian coast. The results obtained in the research carried out by Tomas Nautika Yachting in 2017, showed visible changes in the attitudes and the consumption in Croatia as compared to the year 2012, when the last research was carried out. According to this research, the average daily consumers' consumption was 126 euros per day, thus representing a $26 \%$ growth as compared to the year 2012 .

Portugal, through its history connected to maritime discoveries of new continents, has maintained a close 
relationship with the sea through its culture and way of life. At the same time, and with regard to nautical activities such as sailing, it has had neither the attention of the population nor a sufficient number of practitioners in order to create a relevant critical mass. If there is a critical mass, it enhances the need for more and better nautical tourism ports. Although the country has a poorly indented shoreline, it has one of the world largest exclusive maritime economic zone. It is also situated at the crossroads of important maritime routes between Central and Northern Europe and the Mediterranean, and between America and Europe.

In this sense, the Portuguese government has already been giving major attention, in recent years, through the creation of the Ministry of the Sea. With regard to recreational boating and yachting, the practice of sailing for young people is being promoted in various schools. In terms of public-private partnerships, the promotion of various nautical activities has been implemented by the Ministry of the Sea and the Fórum Oceano (a group of associates from various areas of the economy and scientific research). This association, the Forum Oceano, has, as its vision, the maritime activities as dynamic and competitive segments of the economy capable of valorising the sea and its resources, generating value and creating qualified employment, contributing to the strengthening of Portugal's position within the global economy. In relation to recreational boating and yachting, the general plan of action goes through three axes: construction of a nautical brand, offering a qualification and international promotion.

Although nautical tourism in Portugal is at a lower level than in Croatia, there are signs of changes that are already taking place through the recent foundation of the Ministry of the Sea, the creation of an association of entities interested in maritime economy, the emergence of the first satellite accounts of nautical tourism and its impacts, as well as through scientific researches carried out in this segment of tourism and its current and future importance to Portugal.

\subsection{Measures for Future Development}

The Republic of Croatia has natural, hydrographic and climate preconditions for the development of nautical tourism. The goals set for the development of nautical tourism has clearly arisen from the vision that Croatia should become one of the most desirable nautical destinations in the Mediterranean. In order to achieve this Croatia has to construct a new nautical infrastructure, renovate the old one or reconstruct some existing areas within nautical tourism ports. The Strategy for the Development of Nautical tourism in Croatia for the period 2009-2019 has proposed the construction of 5000 new berths at the already existing nautical tourism ports, 5000 berths in new locations and 5000 boat places on land for the accommodation of yachts which would be evenly distributed along the Croatian coast and on the islands. It has been emphasizes that during the planning of the construction of berths, it is necessary to take into account the rising trend in the arrival of large yachts that the already existing infrastructure is not able to accommodate. It is obvious that the problem of the layout and arrangement of nautical tourism port still exists and will be one of the key strategic objectives of the macro-development policy in the future.

The construction of new berths and the enrichment of nautical tourism offers will have both direct and indirect benefits. For this reasons, regional and local authorities must play a very important role in the development of nautical tourism. It should be also considered that social and economic requirements have to be in accordance with ecological impacts.

Due to the lack of centralism that nautical tourism still has in Portugal, its development is still at an early stage of development, so that the so-called Nautical Portugal Project (Fórum Oceano) presents the generic indications that the country should follow. This project focuses on the development of an entrepreneurial network that adds, fosters and consolidates Portugal's competences in the recreational boating and yachting sector, building an integrated, competitive and credible offer and promoting and disseminating it internationally. The recommendations are: to establish international partnerships, to attract crafts for wintering purposes in Portugal, to make the stay in Portugal a competitive one, to provide a unique leisure and entertainment experiences for nautas, to take advantages of Portuguses nautical references (Portuguese role models), and to make Portugal an excellent training centre in Europe.

To this end, the project proposes to develop an integrated strategy, promoting complementariness both from a territorial and sectoral point of view, since it is fundamental to create a critical mass that will enable the initiative to be achieved. This integrated strategy should include the creation of tourismt destinations to promote charter activities and improve boat and yacht maintenance and repair; the maximization of historical legacy, the maximization of the potential of the integrated nautical infrastructures in the cities' economy, to stimulate relevant events, to streamline the industrial production of products and services intended for nautical sports and leisure, and to develop the various segments of recreational boating and yachting.

\section{Conclusion}

Nautical tourism is considered to be one of the most developed segments of tourism in Croatia and has marked a continuous growth in the last decades. However, its developing potential has not reached suitable economic impacts. Regarding Portugal, despite the significant annual flow of yachts passing along the coast, it has only been possible in recent years to bring together public and private entities around a macro objective concerning the development of the economy of the sea. Faced with this awareness and with the first measures put into practice, it can be expected that the years to come will bring a greater relevance to Portugal, in the European context, as a destination for nautical tourism. 


\section{Acknowlegments}

This work was co-financed by the European Regional Development Fund (ERDF) through the COMPETE 2020 - Operational Programe Competitiveness and Internationalization (POCI) and national funds by FCT under the POCI-01-0145-FEDER-006891 project (FCT Ref: UID / GEO 04084/2013).

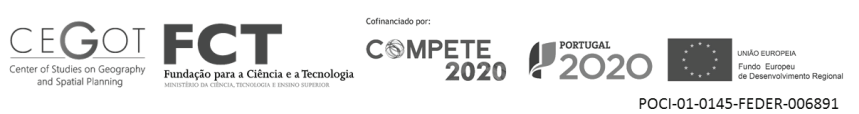

\section{References}

[1] Croatian Bureau of Statistics (2018), Nautical tourism, Capacity and Turnover of Ports. [online] Available at https://www. dzs.hr/Hrv_Eng/publication/2017/04-03-04_01_2017.htm

[2] Duplančić, Leder T., Ujević, T., Čala, M. (2004). Coastline Lengths and Areas of Islands in the Croatian Part of the Adriatic Sea Determined from the Topographic Maps at the Scale of 1:25.000. Geoadria, 9, pp. 5-32.

[3] Gračan, D., Alkier Radnić, R. (2003). Kvantitativna i kvalitativna obilježja nautičkog turizma u strategiji razvitka hrvatskog turizma, Pomorski zbornik, 41, pp. 309-318.

[4] Grupo de trabalho da náutica de recreio. (2012). Náutica de recreio em Portugal - Um pilar do desenvolvimento local e da economia do mar. 1st ed. Óbidos: Sinapis Editores.

[5] Institute of tourism (2018). Tomas Nautika Yachting 2017, Zagreb: Institute of tourism.

[6] Jugović, A., Kovačić, M., Hadžić, A. (2011). Sustainable development model for nautical tourism ports. Tourism and hospitality management, 17(2), pp. 175-186.

[7] Kovačić, M. (2012). Sustainable development of nautical tourism in Croatia. In: L. Rosalino, A. Silva, A. Abreu, eds., New Trends Towards Mediterranean Tourism Sustainability, $1^{\text {st }}$ ed. Hauppauge NY: Nova Science Publishers, Inc., pp. 95-118.

[8] Kovačić, M., Favro, S., Mezak, V. (2016). Construction of nautical tourism ports as an incentive to local development. Environmental Engineering and Management Journal, 15(2), pp. 395-403.

[9] Kovačić, M., Luković, T. (2007). Spatial characteristics of planning and construction of nautical tourism ports. Geoadria, 12(2), pp. 131-147.
[10] Law on Providing Tourism Services (NN Nos. 130/17).

[11] Law on Tourist Activity (NN, Nos. 8/96, 19/96, 76/98, 76/99).

[12] Lukovicě, T. (2013). Tourism and nautical tourism. In: T. Lukovicě, ed., Nautical tourism, 1st ed. Oxforshire: Cabi Publishing, pp. 5-32.

[13] Ministry of Sea, Traffic and Infrastructure, Ministry of Tourism. (2008). Strategija razvoja nautičkog turizma Republike Hrvatske za razdoblje 2009-2019. Zagreb, Croatia.

[14] Orams, M. (1999). Marine Tourism: Development, Impacts and Management. 1st ed. London, UK: Routledge.

[15] Ordinance on Classification and Categorisation of Nautical Ports (NN, Nos 142/99, 47/00, 121/00, 45/01, 108/01).

[16] Ordinance on Classification and Categorisation of Nautical Ports (NN, Nos. 72/08).

[17] Perna, F., Custódio, M, \& Oliveira, V. (2015). Estudo sobre o impacto económico e turístico de cenários de desenvolvimento da náutica de recreio nas marinas e portos de recreio na área de jurisdição da docapesca - Relatório 2. University of Algarve.

[18] Provision of Tourism Services Act (NN, Nos. 68/07).

[19] PwC (2016). Náutica de recreio em Portugal - Uma perspectiva da procura. PwC Portugal.

[20] Regulation on Management and Protection of Coastal Marine Areas, "Official Gazette" 128/04.

[21] Sariisik, M., Turkay, O., \& Akova, O. (2011). How to manage yacht tourism in Turkey: A swot analysis and related strategies. Procedia - Social and Behavioral Sciences, 24, 10141025. doi:10.1016/j.sbspro.2011.09.041

[22] Silveira, L. (2016). O turismo de iates - Estratégia de desenvolvimento para a Figueira da Foz. University of Coimbra.

[23] Sousa, J. F., Fernandes, A., and Carpinteiro, A. (2009). 0 Desenvolvimento das actividades náuticas de recreio como estratégia de valorização territorial: um olhar sobre o Estuário do Tejo. In: $1^{\circ}$ Congresso de Desenvolvimento Regionald de Cabo Verde. Cabo Verde - Redes e Desenvolvimento Regional, pp. 2475-2494.

[24] Verdet, A. P. (2002). Puertos deportivos: repercusión de su administración y gestión en el desarrollo del turismo náutico. Estrategias para el caso de la Costa del Sol. Universidad de Málaga.

[25] Zelenika, R. and Vidučić, V. (2007). Model razvitka nautičkog turizma u Republici Hrvatskoj do 2015. godine, Ekonomski pregled, Vol. 58 No. 9-10, pp. 522-544. 